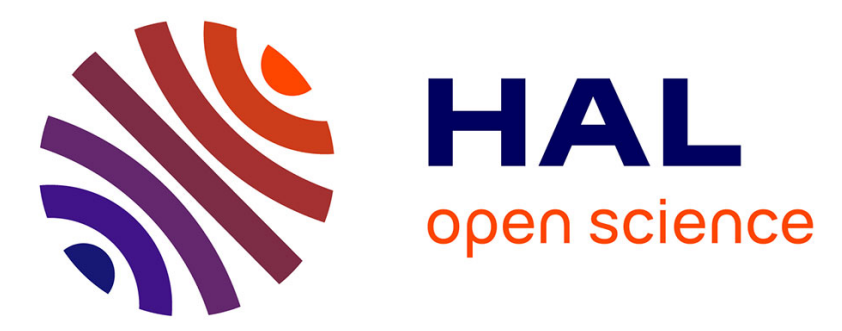

\title{
Experimental study of the thermal performances of a composite roof including a reflective insulation material under tropical humid climatic conditions
}

Frédéric Miranville, Eric Fock, François Garde, Patrick Hervé

\section{- To cite this version:}

Frédéric Miranville, Eric Fock, François Garde, Patrick Hervé. Experimental study of the thermal performances of a composite roof including a reflective insulation material under tropical humid climatic conditions. World REnewable Energy Conférence, Jul 2000, Brighton, United Kingdom. pp.1-5. hal-01067723

\section{HAL Id: hal-01067723 \\ https://hal.science/hal-01067723}

Submitted on 24 Sep 2014

HAL is a multi-disciplinary open access archive for the deposit and dissemination of scientific research documents, whether they are published or not. The documents may come from teaching and research institutions in France or abroad, or from public or private research centers.
L'archive ouverte pluridisciplinaire HAL, est destinée au dépôt et à la diffusion de documents scientifiques de niveau recherche, publiés ou non, émanant des établissements d'enseignement et de recherche français ou étrangers, des laboratoires publics ou privés. 


\title{
EXPERIMENTAL STUDY OF THE THERMAL PERFORMANCES OF A COMPOSITE ROOF INCLUDING A REFLECTIVE INSULATION MATERIAL UNDER TROPICAL HUMID CLIMATIC CONDITIONS
}

\author{
F. MIRANVILLE, E. FOCK, F. GARDE, P. HERVE
}

\begin{abstract}
Université de La Réunion, Laboratoire de Génie Industriel, Faculté des sciences 15 avenue René Cassin, 97715 Saint-Denis, La Réunion, FRANCE
\end{abstract}

\begin{abstract}
This paper deals with the evaluation of the outdoor performances of a composite roof, composed of a corrugated iron rooftop, a radiant barrier and a ceiling made of wood, each component being separated by an air space. This assembly is mounted on a small-scale test cell, named Isotest, designed and set up for research purposes. Isotest is installed on an experimental platform, dedicated to the complete study of the outdoor performances of radiant barrier systems. After an introduction to the study, the entire experimental disposal is described in details. The results are then presented, followed by an analysis.
\end{abstract}

\section{KEYWORDS}

Passive cooling; thermal insulation; solar protection; outdoor measurements; instrumentation.

\section{INTRODUCTION}

\section{The Need for Bioclimatic Architecture}

Reunion Island is characterised by a tropical and humid climate, with an important ambient humidity and an intense solar radiation. Such a climate imposes extreme solicitations to the various components of a building and often creates totally unaffordable discomfort situations. To face this problem, the use of HVAC systems turned out to be the solution, despite of the generated rise in energetic building consumption. Nevertheless, with the growing difficulty for energetic supply, increased by the situation of insularity, improving building design with the use of efficient thermal insulation materials to reduce the energetic consumption, appeared to be a necessity.

\section{$\underline{\text { Radiant Barriers }}$}

Radiant barriers are materials that are installed to reduce summer heat gain and winter heat loss, and hence to reduce building heating and cooling usage. They usually consist of a thin sheet or coating of a highly reflective material, usually aluminium, applied to one or both sides of a number of substrates materials (for example Kraft paper or plastic films). They are included in roofs between the rooftop and the ceiling, most of the time stapled on the rafters (Fairey, 1994a). Radiant barriers take a great advantage of their reflective sides, whose low emissivity constitutes the basis of their efficiency (Fairey, 1994b). Contrary to classical 
insulation materials, radiant barriers aim to significantly reduce the radiative heat transfer from the rooftop to the ceiling, by reflecting up to $95 \%$ of the incident radiant energy and emitting only $5 \%$ of it. As the incident energy generally comes from the rooftop, directly exposed to solar radiation, an air space is necessary between the rooftop and the radiant barrier, so that the heat transfer between these two components is in a majority by thermal radiation.

\section{INSTRUMENTATION}

\section{The Experimental Disposal}

The experimental disposal includes an experimental platform and a small-scale test cell, Isotest (Miranville, 1999). The experimental platform $(12 \times 21 \mathrm{~m})$, dispose of five locations for five small-scale test cells (approximately $1 \mathrm{~m}^{3}$ ) and one location for a large-scale test cell (approximately $27 \mathrm{~m}^{3}$ ). These locations, as shown on Fig. 1, have been determined according to the trajectory of the sun to permit the same influence of the solar radiation for each test cell and to allow constant sun exposure with no shading.

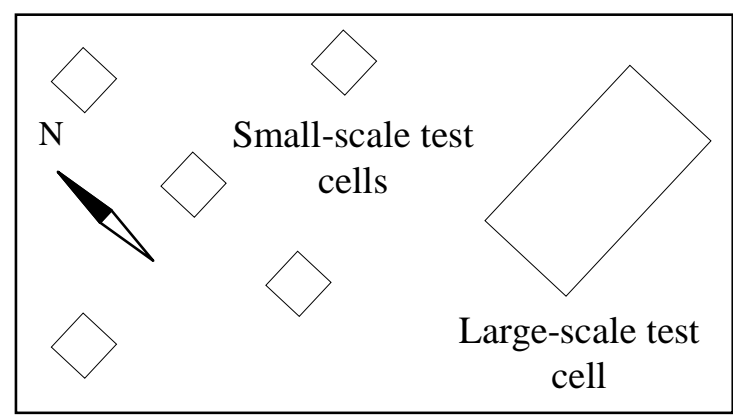

Fig. 1. The experimental platform

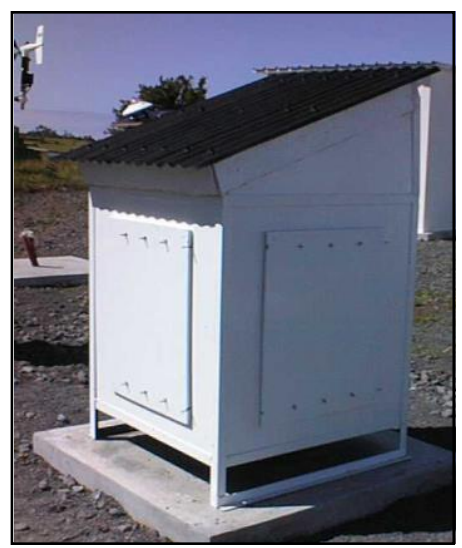

Fig. 2. Isotest test cell

Isotest (see Fig. 2) is a small-scale test cell equipped with a composite roof composed of a corrugated iron rooftop, a two reflective sides radiant barrier and a ceiling made of an eight millimetres thick plywood board. Between the rooftop and the radiant barrier, an eight centimetres thick air space is present and between the radiant barrier and the ceiling, there is a three centimetres thick air space. To impose extreme solicitations on the tested composite roof, the rooftop is painted in black and the lateral panels and the floor are insulated with polystyrene boards. The upper air space included in the roof assembly can be ventilated or not, permitting to observe the influence of the ventilation conditions on the global performance of the tested radiant barrier.

\section{The Sensors and the Data Acquisition System}

Concerning the composite roof, flux measurements through the rooftop, the radiant barrier and the ceiling, using square fluxmeters, are made ; then, the surface temperature of the previous elements are measured, using type $\mathrm{T}$ thermocouples; the temperatures in the air spaces are also monitored, using thermocouples protected from the influence of the ambient radiation by an aluminium cylinder ; finally, to measure the incident solar radiation on the roof, a pyranometer is installed on one side of it, following the same slant. The various sensors are connected to a data acquisition system, which controls the data measurement sequence and also the data storage. 


\section{EXPERIMENTAL PROCEDURE}

\section{The Methodology}

Our main concern was to find an appropriate indicator of the efficiency of the composite roof according to the incident solar radiation. This guiding line led us to evaluate the performance of the roof with the Solar Transmission Factor (STF). This coefficient offers the advantage to be a very intuitive parameter and also to be easily interpreted. Indeed, its value is simply the ratio of the energetic flux transmitted through the concerned wall to the incident energetic flux. Nevertheless, such a factor is only significant in steady-state conditions. That's why we decided to divide a complete day in hourly parts, and to consider calculating one value of the $S T F$ for each part, by averaging the data collected on one hour. The composite roof being composed of materials with a low thermal inertia, we can also consider the complete assembly to have a low thermal inertia too. Therefore, it is possible to consider transient conditions as consecutive steady-state conditions (Baronnet, 1985). Hence, with this procedure, it is possible to use the STF to characterise the solar protection of the composite roof along a day, and to focus on the critical daily period, from 10 am to 2 $\mathrm{pm}$ (when the intensity of the solar radiation is high, $600 \mathrm{~W} / \mathrm{m}^{2}$ on average), to evaluate the corresponding roof efficiency.

\section{$\underline{\text { Measurement Results and Analysis }}$}

First case : non-ventilated upper air space. Figure 3 shows the flux measurements through the rooftop, the radiant barrier and the ceiling : the three curves vary approximately simultaneously. This indicates that the composite roof has a low thermal inertia. This comment is important because it confirms the theoretical hypothesis and allows the use of the $S T F$ as a convenient indicator. Secondly, the flux through the rooftop reaches a maximum of approximately $40 \mathrm{~W} / \mathrm{m}^{2}$, whereas the two other are on average respectively about $8 \mathrm{~W} / \mathrm{m}^{2}$ for the reflective insulation and $6 \mathrm{~W} / \mathrm{m}^{2}$ for the ceiling. The mean flux transmitted to Isotest's structure is only about $6 \mathrm{~W} / \mathrm{m}^{2}$, which is few comparing to the incident solar radiation of approximately $900 \mathrm{~W} / \mathrm{m}^{2}$. Moreover, the hourly evolution of the $S T F$ (see Fig. 4) shows a good performance of the composite roof. Its value of 0,0055 on average for the critical daily period is low, and comparing to the standard recommended value for well-protected roofs (Célaire, 1997) ( $S T F \leq 0,014$ ), demonstrates a significant efficiency.

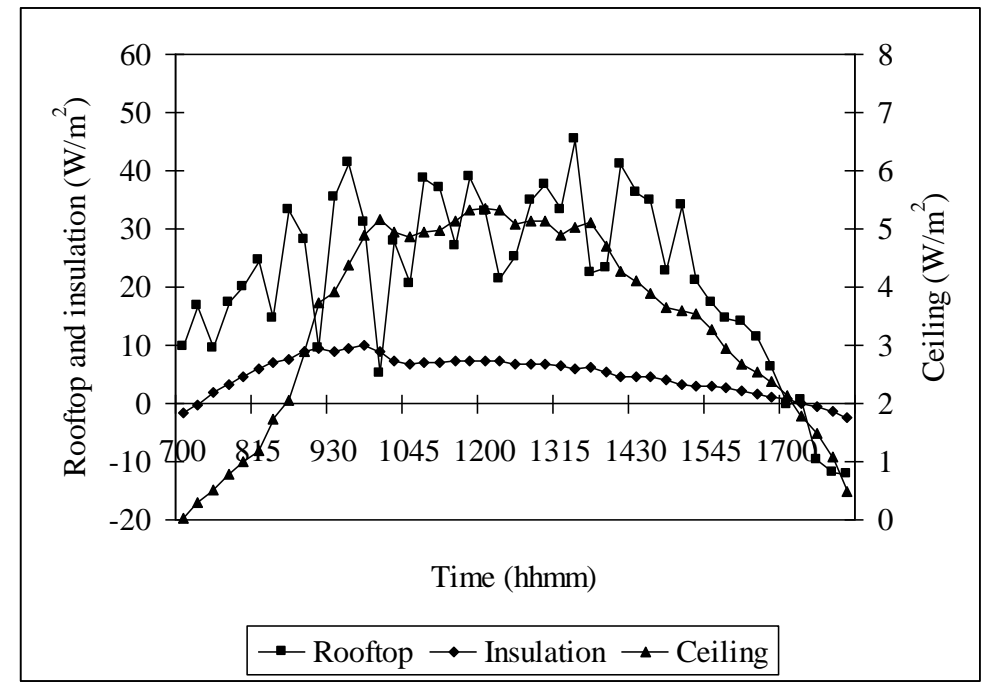

Fig. 3. Flux density through the composite roof non-ventilated air space

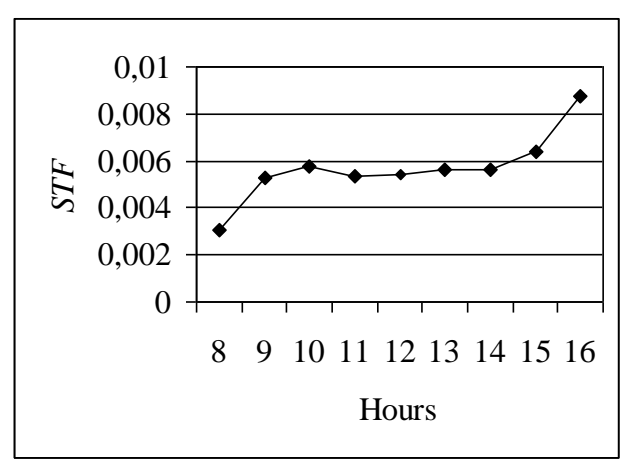

Fig. 4. Hourly $S F T$

Second case : ventilated upper air space. The corresponding results are shown on Fig. $5:$ the flux through the rooftop is much more important and reaches a maximum of approximately $150 \mathrm{~W} / \mathrm{m}^{2}$. Flux variations 
concerning the insulation and the ceiling are sometimes negatives. This points out an inversion of the flux direction. The ventilated upper air space generates energetic flux through the insulation and the ceiling that can vary significantly. The knowledge of the air speed within the air space would permit a better interpretation of the results. This is scheduled in the following period of measurements. Nevertheless, the flux transmitted to Isotest's structure is about $0,5 \mathrm{~W} / \mathrm{m}^{2}$ between 10 and 13 hour, representing an efficient solar protection. The $S T F$ is also well perturbed by the ventilated air space, and is sometimes negative due to the inversion of the flux direction. Nevertheless, considering only the positives values (acceptable restriction according to the critical daily period) the good performance of the composite roof is demonstrated, with a value of 0,0012 .

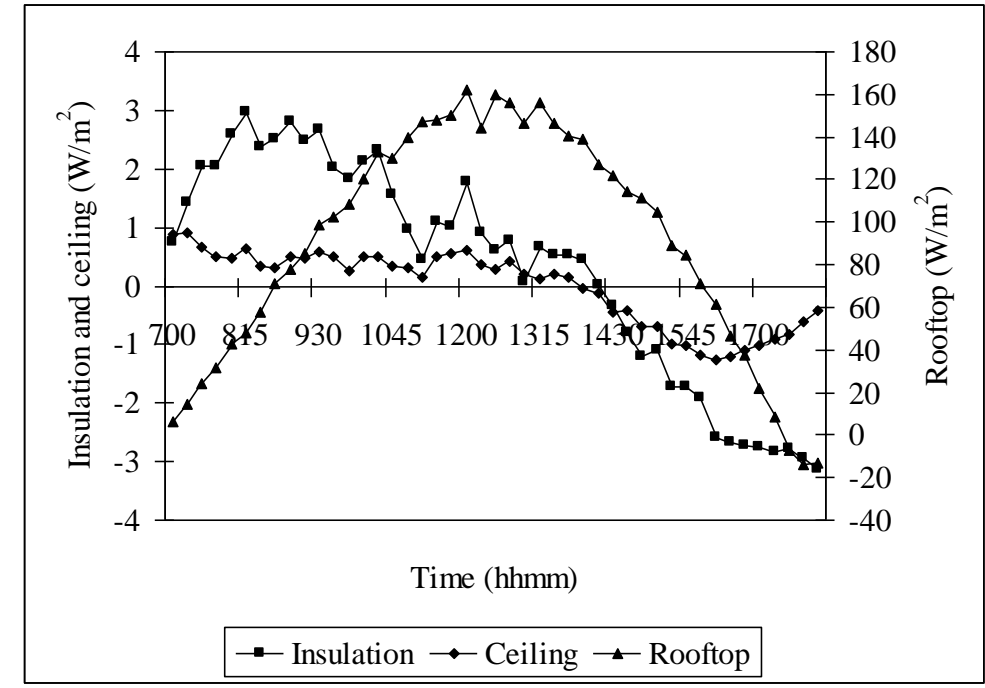

Fig. 5. Flux density through the composite roof ventilated air space

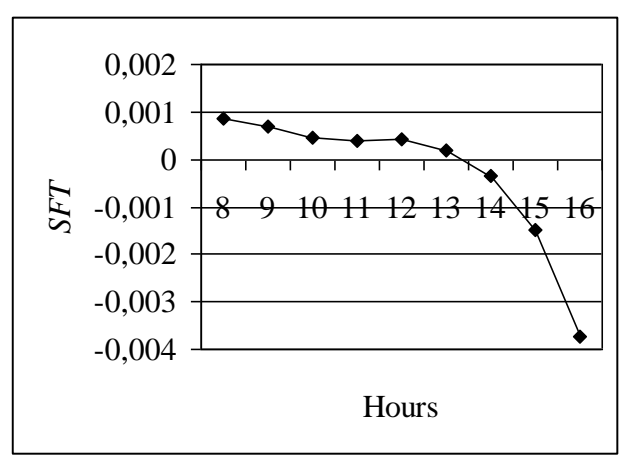

Fig. 6. Hourly $S F T$

\section{CONCLUSION}

This preliminary study shows interesting results and tends to confirm the great potential of radiant barrier systems in tropical humid climatic conditions. It also permitted to determine that the performances of such an assembly are closely linked to the ventilation conditions in the air space facing the reflective side of the radiant barrier. Under the climatic conditions of the study, a ventilated air space has proved to give better performances. Nevertheless, this fact should not be generalised. To have more complete information, the study must be implemented during a typical summer period, under extreme climatic conditions.

\section{REFERENCES}

Baronnet, F. (1985). Etude thermique de l'habitat individuel à La Réunion, Thèse : Sci. : Université de Paris VII.

Fairey, P. (1994a). Designing and installing radiant barrier systems, Design note 7, Florida Solar Energy Center, Cape Canaveral, Florida.

Fairey, P. (1994b). Radiant energy transfer and radiant barrier systems in buildings, Design note 6, Florida Solar Energy Center, Cape Canaveral, Florida.

Miranville, F. (1999). Mise en place d'une plate-forme expérimentale - Réalisation et instrumentation d'un dispositif de caractérisation d'isolants minces réfléchissants, Mémoire de DEA, Université de La Réunion.

Célaire, R. (1997). Opération expérimentale Label ECODOM. Prescriptions techniques, document de référence. $32 \mathrm{p}$. 